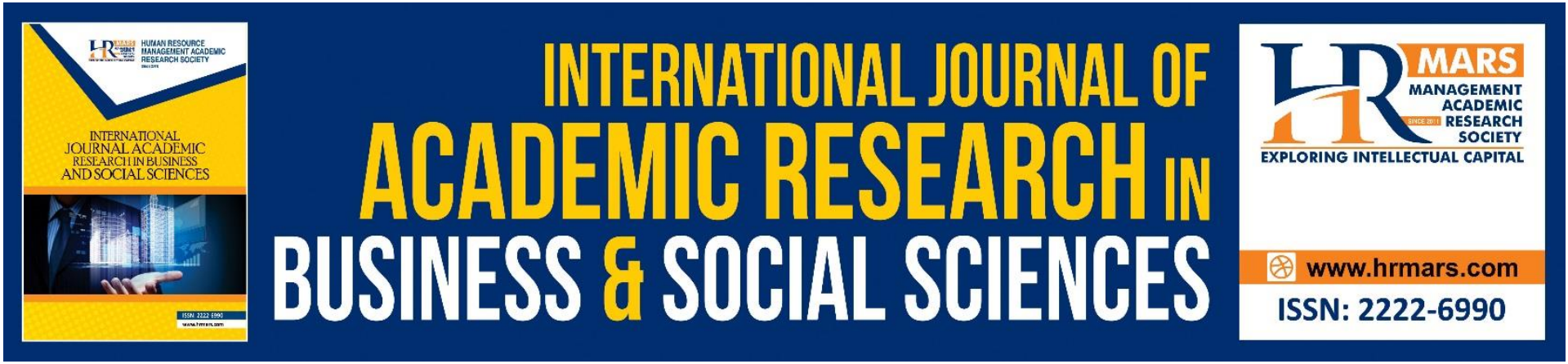

\title{
Customers' Perception on Malaysian Street Food Quality
}

\section{Firdaus Abd Hanan, Nurulain Binti Sadri, Nur Qamar Binti Yusup}

To Link this Article: http://dx.doi.org/10.6007/IJARBSS/v11-i13/8503

DOI:10.6007/IJARBSS/v11-i13/8503

Received: 16 November 2020, Revised: 13 December 2020, Accepted: 10 January 2021

Published Online: 23 January 2021

In-Text Citation: (Hanan et al., 2021)

To Cite this Article: Hanan, F. A., Sadri, N. B., \& Yusup, N. Q. B. (2021). Customers' Perception on Malaysian Street Food Quality. International Journal of Academic Research in Business and Social Sciences, 11(13), 7387.

Copyright: (C) 2021 The Author(s)

Published by Human Resource Management Academic Research Society (www.hrmars.com)

This article is published under the Creative Commons Attribution (CC BY 4.0) license. Anyone may reproduce, distribute, translate and create derivative works of this article (for both commercial and non-commercial purposes), subject to full attribution to the original publication and authors. The full terms of this license may be seen

at: http://creativecommons.org/licences/by/4.0/legalcode

Special Issue: Beyond 2021 and COVID-19 - New Perspective in the Hospitality \& Tourism Industry, 2021, Pg. 73 - 87

Full Terms \& Conditions of access and use can be found at http://hrmars.com/index.php/pages/detail/publication-ethics 


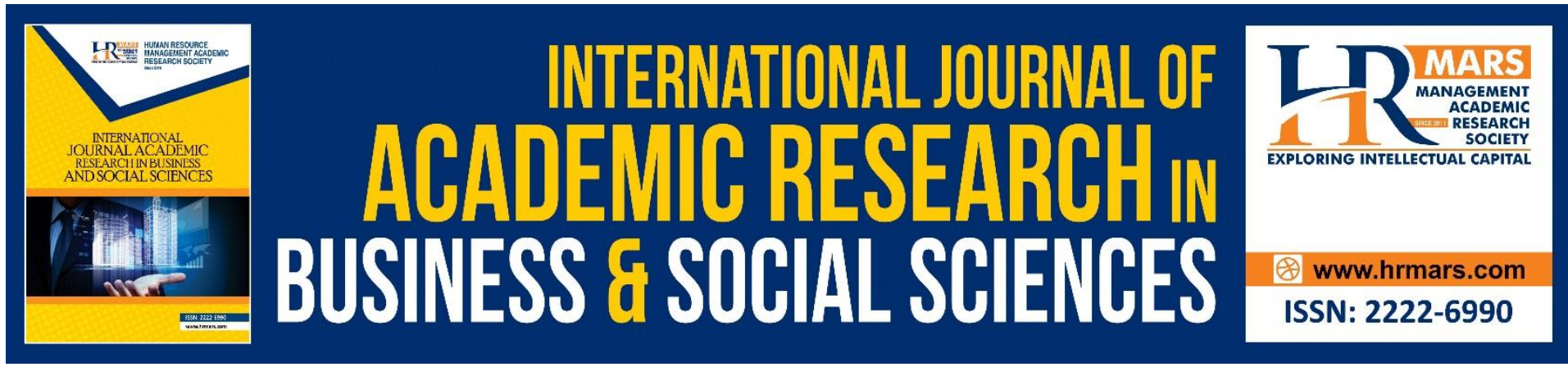

\title{
Customers' Perception on Malaysian Street Food Quality
}

\author{
Firdaus Abd Hanan, Nurulain Binti Sadri, Nur Qamar Binti \\ Yusup \\ Faculty of Hotel and Tourism Management, Universiti Teknologi MARA, Puncak Alam \\ Campus, 42300, Selangor, Malaysia
}

\begin{abstract}
In a developed country like Malaysia, street food is an important culture that not only provide the means for income generation to the people, it is also a crucial part of culinary scene. However, over the years problem with foodborne illnesses involving this type of business has been identified as one of the main culprits, nevertheless the consumers still view street food as an essential provider for their daily meals. This study is conducted to identify the factors that influence Malaysian perceived quality regarding street food. A survey questionnaire among customers at three Pasar Malam has been undertaken with a total of 100 respondents where all the data were found usable. The survey was conducted at Kampung Baru Night, Taman Connaught and Little India, Brickfield. The results from descriptive analysis revealed that most of the respondents believe cleanliness is the most important factor in choosing the stall. The outcome also indicated that organization of the stalls will sway their decision in buying foods from certain vendors. Meanwhile service and the healthiness of the food offers is the least of their concern among these four factors.
\end{abstract}

Keywords: Perceived Quality, Cleanliness, Healthiness, Organization and Service

\section{Introduction}

Foodborne diseases are caused by food that had been contaminated by microbiological contamination, which is naturally produced toxins or chemicals in food that was mishandled (Van Seventer \& Hamer, 2017). In Southeast Asia countries including Malaysia, unhygienic practices are the foremost caused of foodborne diseases mainly by street food vendors and schools canteen operator that both were found to be common conditions for foodborne outbreaks (Dewanti-Hariyadi \& Gitapratiwi, 2014). This finding supported a previous study by Soon, Singh, \& Baines (2011), that institute in Malaysia, almost $50 \%$ of all foodborne diseases which is from the reported food poisoning cases were identified as caused by unsanitary food handling practices. Factors like establishment features, poor local infrastructure, product characteristics sold and lack of sanitary surveillance, raise concerns about the safety of food sold on the street (Shafiee et al., 2017). Mutalib, et al (2015) revealed that cases of food poisoning are not rare in Malaysia because the country's weather is hot and humid climate is 
very conducive for the growth of foodborne bacteria. In times of economic crisis and job loss, or when there are migration/ immigration movements, street food trade is an alternative to the family income.

Street foods are normally cheap, easy to be transported around and convenient to be sold using vans or kiosks that are usually located on commercial streets and at festivals (Bellia et al., 2016). Over the years, street foods have been the subject of many researches either from economic, social and cultural importance or its implications of public health (Alimi, 2016; Basinski, 2014). There had also been studies related to street food that were looking into the food storage and manufacturing conditions as well as its relationship to general public health. Ekanem (1998) that studied the South African street food found that, consumer believed that there were no minimum standards in food production to protect the health of consumers, the research also indicates the need for more government regulation for this type of trade, in terms of sanitation guidelines. Previous investigation by Benny-Ollivierra \& Badrie (2007) had found that the conditions of street food trade in open-air festivals, noting that merchants often handle food and money resulting in low hygiene conditions. In 2018, Malaysian was shocked with a video that went viral over dirty eateries and unhygienic practices by few eateries found in several locations in Petaling Jaya, this has led to people becoming more conscious in choosing which food outlets they patronise, (The Star Online, 2018). In 2019, many people were horrified when a video showing workers of a restaurant in Bangsar washing dishes in a puddle of murky water in a back lane, became public.

However, even with these worrying concrete proof on the safety involving food from street vendors, there were more than 2.5 billion consumers that get their daily meals from street food all over the world daily, in India, 2.5 percent of the country's population is projected to be called street vendors, meanwhile in Latin America countries, street food is spent on more than 30 percent of household budgets in urban centers (Bellia et al., 2016). There were over 11,000 street stalls/kiosks in Malaysia in year 2012 with a total transaction of over 490 million dollars. Outlets and transactions increased at annual levels of $6.2 \%$ and $5.9 \%$ respectively between 2008 and 2012, these street food vending in Malaysia are considered to be one of the main sources of income for the people who generate a multi-million dollar to vendors and food handlers (Alimi, 2016; Shafiee, Karim, Razali, \& Abidin, 2017). This has led into the undergoing on this research that investigates on the main criteria by the consumer in choosing the street vendors that is perceived to be safe. The main objective of this research is to explore the relationship between service, organization, healthiness and cleanliness towards perceived quality of street food specifically sold at pasar malam by Malaysian consumer.

\section{Literature Review \\ Perception on Quality}

Perception towards the overall quality relies on the variables that customers use to view and judge a service or product, understanding and identifying the crucial characteristics are critical to shed some light on consumer behaviour (Ibáñez Casanova, 2003). According to Grunet (2010) quality is tangible it is a criterion that was formed by the consumer before they made the purchase and once again after they had consumed the product. The researcher further argued that it is generally agreed that consumer's feeling regarding the quality of the products is significant whether in the case of indoor and outdoor food, the latter being 
represented by street commerce. Customers' perception on the final quality are often the outcomes made by them in between their expectation before buying the product and the performance (taste) (Tinoco \& Ribeiro, 2008).

Tiwari and Verma (2008) found that the justifications for this market's growth of street food vendors are the cheap price and the ease in preparing food that is commonly sold. These factors must be combined with the perception of quality formed by customers through the assortment of food, taste, climate and hygiene, speed of service, location and parking, and these variables influence the choice for consumers. Almeida et al. (2014) say that such variables should also be correlated with the understanding of price in street food commerce. Brunso et al. (2002) further supported the discussion with emphasizing the effect of taste and appearance, healthiness, convenience and processing in Western industrialized countries as important variables in food trade.

Regarding the market understanding, the literature on street food specifically is sparse and does not explicitly define the antecedents of perceived quality. On the basis of the literature on the subject and the food trade consumed away from home, however, potential quality determinants have been identified (Santos et al., 2012; Tinoco and Ribeiro, 2008), which will be discussed by adapting from the research by Tinoco \& Ribeiro (2008) that posited the perceived quality of food consumed away from home can be made from the i) service perform by the sellers, ii) organization (in terms of display, the arrangement), iii) cleanliness and the iv) healthiness: operation, organization, cleanliness and healthiness.

\section{Perception on Service, Organisation, Healthiness and Cleanliness}

Rheinländer et al. (2008) showed that, trust that had been built by famous street vendors through years of operating had been recognised as one of the most important decisive factors in choosing a location for street food, despite the general scepticism. The researcher further explained that many customers claimed that this relationship confidence with established vendors would influence their overall perceived quality even having doubt on their general food safety in the street food trade.

Great customer support services will concentrate on customer well-treatment, answering questions, and exceeding expectations. Alexander (2006) states that delivering services means dealing personally with customer personnel and, done properly, starts to build trust-based relationships. If the consumers are happy, they are more likely to spread the goodness to friends, family and colleagues. In fact, 77 per cent of customers shared positive brand experiences with others according to the same research. 64 per cent of people find customer service is more important than price when it comes to making a purchase. When asking customers what effect their confidence level with a business has, Dimensional Research (2019) provides excellent customer service ranked number one.

To ensure the longevity and perpetuation of a restaurant business, it has been established through various research over multiple settings which were done over the years that recognize service as an extremely important role (Fontanillas et al., 2013). The authors found that people shape expectations regarding the quality of service regardless of the product or service they are seeking. Consuming street food is not only about fulfilling one physiological 
need as a human, it goes beyond that, in most countries the interaction and communication between individuals that involves during transaction has also been pointed out to be crucial (Santos et al., 2012). The researchers had also pointed out several other reasons that determine street food acquisition; these factors sometimes even triumph the suspicions a customer has in the possibility of falling ill thru doubtful quality standard by certain street food vendors operators, consumers seek some reciprocity from the place where they eat, expressed in the form of good service (Rossi et al 2012). This good service is represented by the cleanliness, behaviour, politeness and attentiveness of the vendors.

In street food acquisition, aesthetics and organization of food at the point of sale has also been found to be vital deciding factors by the consumer (Drechsel et al., 2000; Probst, 2008; Rheinländer et al., 2008). Grunert et al. (1996) in studying food that was eating away from home, found strong correlation between the location and perceived quality. Consumer often uses location as one of the main indicators in evaluating the expected quality. However, food, tools, and storage of ingredients that are not handled properly during sales period have been reported to be contaminated with the presence of insects at points of sales (Lucca \& Torres, 2002).

Grunert (2010) proposes the idea that health is an intangible commodity in economic terms which means that consumers cannot access it directly. For Schnettler et al. (2015), the understanding of healthy food intake is implicitly related to disease prevention and improvement in health. According to Chrysochou \& Grunert (2014), well-being elements can have a positive effect on consumer health evaluations of goods and promote purchase. There are few studies on perception of product healthiness in Brazil, according to Viana (2013); the perception on the risk involved in consumption is inversely related to the product's healthiness. Parry et al. (2004) comment that perceived risk of street food is lower than perceived risk of trade domestic environments. Therefore, in order to reduce cases of foodborne illnesses due to food poisoning, it is important to verify the risk conditions, which invariably will strengthen general perception on health. Santos et al. (2012) in his consumer research in Bahia, argues that the quality of street food can only be lifted through educating user on what constitute as a healthy choice, this will then put a demand on the sellers to offer such options. Asiegbu et al. (2016) have conducted a study in Johannesburg, South Africa that is looking at the perceived biological risk of street food consumer by assessing their knowledge regarding food safety found that there is a gap in the knowledge, attitude and practices when buying and consuming food sold by streets vendors. The principle consumption of these goods are accessibility, quality and comfort. Many customers did not trust the food safety sold, but that had no effect on their choices.

Stojanovic et al. (2013) provide another interesting research that suggests, people who are accompanied by children will more likely to choose food products that look better, i.e. the presence of children affects the interpretation of quality in terms of the gain linked to the purchased food. In another context, Schnettler et al. (2015) associate the purchasing of healthier foods to countries where lifestyle changes are taking place, in which street food consumption is also affected by the desire for healthier foods, as the selling of nutritious items is not a common occurrence in closed environments, such as fast food. 
Diulio (2010) emphasised that a business place with high level of cleanliness and sanitation has a higher chance in attracting new customers and retaining existing ones. In another research that looked into the importance by quick-service clients on crew uniforms by Decision Research Inc highlighted cleanliness to be on the top ahead of other factors such as fit, style, color and even the design's "age-appropriateness." Consumer in today's world is more than just savvier, they also have much limited amount of money which they are willing to spend, Porry (2010) said that they're going to pick the place they think is clean and neat and provide good service to them. They are going to spend their money where they do not have to worry about health issues, clutter, and all the rest that are going to make sure a place is clean. Cleanliness is one of the important factors that always being mentioned while purchasing product, next will be service provided by the sellers, the food sold are safe to consume and the arrangement at the vendors also able to attract the consumer interest.

The areas where street food is mostly criticized and viewed as a health threat are that the places where it is produced and sold are open to dirt and contamination, and that hygiene, attitude, and applications adopted by the sellers during food preparation and storage are insufficient, Ceyhun Sezgin, A., \& Šanlıer, N. (2016). (Van Der Geest, 1998; Drechsel et al., 2000) argues that avoiding dirt at the place of food marketing was already desirable even before bacterial disease transmission was discovered, so cleaning is not only about germ removal and is correlated with moral and cultural problems. For example, in Ghana it has been found that dirt is seen much more as a moral degradation than a potential hazard to the health.

\section{Methodology}

The data for this research were collected directly from the respondent through questionnaire that was distributed to the consumer who visit 'Pasar Malam' or considered as street food market in three places which are Kampung Bharu, Taman Connaught and Brickfields. Kampung Bharu was chosen because the customers are mainly from Malay race, in Taman Connaught most of the customers are Chinese, while in Brickfield it is Indian. This was done so in order to get a clearer insight into the variance races in Malaysia.

The questionnaire distributed consists of two sections which are $A$ and $B$. Section $A$ indicates where the demographic data was collected, and section $B$ is where the four variables statement were elaborated. Section A consists of seven questions which are age, gender, races, income, work, and study level and marriage status. Section B contains four variables and each variable consists of five statements. The variables are cleanliness, healthiness, organization and service. The questionnaire was measured using five points of Likert Scale ranging from 1 to 5 whereby 1 represent "strongly disagree" and 5 represent "strongly agree". Number 2 represent as "disagree" while 3 is "neutral" and 4 is "agree". Each statement in section $B$ required the respondents to rate the scale based on statement given. To test the reliability of the questionnaire, the researcher made a reliability test using pilot study. 10 respondents will be included in the study to get the data. The result of the pilot study will be explained in detail in Table 1. 
Table 1: Reliability Test Results

\begin{tabular}{llcc}
\hline Factor & Cronbach's Alpha & Number of Item & $\begin{array}{l}\text { Number of } \\
\text { Respondent }\end{array}$ \\
\hline Service perception & 0.706 & 5 & 10 \\
\hline Cleanliness perception & 0.745 & 5 & 10 \\
\hline Organization perception & 0.833 & 5 & 10 \\
\hline Healthiness perception & 0.732 & 5 & 10 \\
\hline
\end{tabular}

Pilot study was done with 10 respondents to test the reliability of the questionnaires. The author used coefficient or named as Cronbach's alpha $(\alpha)$ to test the reliability of the question and theoretically scale from 0 to 1 (Cronbach, 1951, Sakaran, 2003) The three factors of this study (service, cleanliness and healthiness) are considered acceptable as all three have $\alpha$ of 0.7 (rounded of $0.706,0.745$, and 0.732 ) as 0.7 is considered acceptable. The organization factor has 0.8 (rounded of 0.833 ) and it is considered good and reliable in this study.

Target population in this study is Kuala Lumpur citizen as it has been reported in World Population Review; the data submitted on December 2019 which approximately 7,900,000 people live in this city. Kuala Lumpur is a capital city and considered an urban city in Malaysia that consists of high number of citizens live in Kuala Lumpur. Most of urbanities in Kuala Lumpur still consume street food such as food from night market or normally called "pasar malam". Based on the Department of Statistics Malaysia, (2010), Kuala Lumpur ethnic composition are $45.9 \%$ Malays, $43.2 \%$ Chinese, $10.3 \%$ Indian and $1.6 \%$ other ethnic. This study managed to get respondents that consists of $63 \%$ Malay, $20 \%$ Chinese, $10 \%$ Indian and $7 \%$ other races which is relevant with the statistic recorded.

Green (1991) gives overview of method used to assess sample size in regression. He recommended $\mathrm{N}>50+8 \mathrm{~m}$ (where $\mathrm{m}$ is the number of independent variables) for examine several correlation and $\mathrm{N}>104+\mathrm{m}$ for examine individual predictors (presuming a mediumsized relationship). In this study, this formula used [ $>50+8(4)=82]$ and get 82 participants as a minimum number of respondents. Total of respondents for this study is 100 respondents which makes it acceptable to complete the study. The data was gathered using simple random sampling method. The questionnaire was distributed randomly to the consumer in each of the location chosen.

\section{Result and Analysis}

The demographic characteristics of the respondents for this study were analysed first. The age of respondents responding to the questionnaire is from age under 20 to above 40 years old. The finding reveals $79 \%$ of the consumer are from age $21-30$ years old. $8 \%$ of the consumers age is $31-40$ years old, $7 \%$ above 40 years old and $6 \%$ is under 20 years old. The respondents are consisting of 37 males and 63 females. 63 from the respondents are Malay, $20 \%$ of them are Chinese and Indian is 10 respondents with others races constitute of 7 respondents The data collected is almost like what we target where the authors' target for Malay races is $60 \%, 20 \%$ for Chinese and $20 \%$ for Indian.

The education level of the respondents, the highest frequency is on the degree level with 56 respondents. On the second is diploma level with 30 respondents, 8 are still on the 
secondary school and the other 6 are on the certificate level. As for the occupation of the respondents, 43 over 100 respondents are still students. 21 respondents answered others occupation other than the one stated in the questionnaire. 16 of the respondents answer professionals as their occupation. 11 of them are government workers. Only 7 respondents work as self-business and the last 2 respondents are full-time housewife.

In terms of the monthly income of the respondent, as most of the respondents are still students, there are 44 respondents answer no income. 26 of the respondents' monthly income is around RM1000 - RM1999. 14 of the respondents' monthly income is around RM2000 - RM2999, 8 of the respondents answered their monthly income is around RM3000 - RM3999 and the last 8 respondents answered others for monthly income. 
Table 2: Factors that Influence Malaysian Perception toward Street Food Quality

\begin{tabular}{|c|c|c|c|}
\hline & Statement & Mean & $\begin{array}{l}\text { Standard } \\
\text { deviation }\end{array}$ \\
\hline 1 & $\begin{array}{l}\text { The cleanliness of the food and environment is } \\
\text { important for me in choosing food to buy. }\end{array}$ & 4.69 & .544 \\
\hline 2 & $\begin{array}{l}\text { Clean stall's environment influences me to choose } \\
\text { street food stall. }\end{array}$ & 4.62 & .599 \\
\hline 3 & $\begin{array}{l}\text { I am attracted to buy something at a stall if the } \\
\text { arrangement is neat. }\end{array}$ & 4.60 & .635 \\
\hline 4 & Service from the seller is important for me. & 4.52 & .717 \\
\hline 5 & $\begin{array}{l}\text { I look at the overall stall's cleanliness before decided to } \\
\text { buy the food. }\end{array}$ & 4.51 & 674 \\
\hline 6 & $\begin{array}{l}\text { I am attracted to buy food at a stall that sells various } \\
\text { type of product }\end{array}$ & 4.46 & 687 \\
\hline 7 & I will not come again to a stall if I get a bad service. & 4.44 & .856 \\
\hline 8 & $\begin{array}{l}\text { I look at the utensil cleanliness that is used by the seller } \\
\text { before I make my purchase }\end{array}$ & 4.42 & .767 \\
\hline 9 & $\begin{array}{l}\text { Good arrangement of food at a stall attract me to buy } \\
\text { food from it }\end{array}$ & 4.41 & .753 \\
\hline 10 & I buy food at a stall a stall that has good decoration & 4.21 & .807 \\
\hline 11 & $\begin{array}{l}\text { I will buy a food at a stall if its seller uses interesting } \\
\text { promotional materials in selling their food }\end{array}$ & 4.16 & .906 \\
\hline 12 & Most of the seller handle food with a clean practice & 4.14 & .921 \\
\hline 13 & Seller are always alert with customer's need & 3.87 & .860 \\
\hline 14 & I choose healthier food at a street food stall & 3.83 & .964 \\
\hline 15 & I am concern about the healthiness of the food I buy & 3.82 & .891 \\
\hline 16 & $\begin{array}{l}\text { I always get good service when buying food at street } \\
\text { food market }\end{array}$ & 3.76 & .637 \\
\hline 17 & $\begin{array}{l}\text { Service that was given by the seller is meeting my } \\
\text { expectations }\end{array}$ & 3.70 & .745 \\
\hline 18 & $\begin{array}{l}\text { The street food seller focusses on healthiness on their } \\
\text { food product. }\end{array}$ & 3.46 & 1.009 \\
\hline 19 & It easy to get a healthy food at the street food stall & 3.12 & 1.148 \\
\hline 20 & The healthiness of food is not important for me & 3.01 & 1.306 \\
\hline
\end{tabular}

Table 2 is showing the mean and standard deviation of each statement in the questionnaire. The item with means response that is higher than 3.5 is considered as important factor that contributes to the factor that influences the perception of product quality for Malaysian street food. This study has found that most of the respondents tend to focus on cleanliness before purchasing food from street with highest mean which is 4.69 . Respondents also agreed that the stall environment cleanliness is an important factor that affects the Malaysian perception on choosing street food vendor with 4.62 mean result. The least high mean is the healthiness factor as the respondents believe that the healthiness is not the main option before purchasing product in street food vendor with mean score 3.01. 
The main objective of the study is to identify the most important factor that influences the perception of product quality towards Malaysian street food by the consumer. Cleanliness has been identified as the most important factor that influences the perception of product quality towards Malaysian street food by the consumer. Decision to assist certain vendors can be imposed by the authority by the educating and imparting the standards hygiene of food and the cleanliness (Auty's, 1992). From the result, the consumer mostly agreed on every statement under cleanliness perception as the mean range is from 4.0 to 4.9 where it is considered agree in Likert scale. The importance of cleanliness including utensils, environment, the food, the way of the food been handled by the seller as well as first impression before coming to the stall is looked by the consumer. From this explanation, it is a fact that healthiness perspectives will positively affect the product quality of Malaysia street food.

From the data gathered, most of the consumers agreed that service from the seller is important for them with the highest mean in service factor; 4.69. The consumer also agreed that they will not come again to the same vendor if they get bad service as the mean result for this statement is 4.62 which is considered agree. The consumers feel neutral about getting the good service during purchasing and meeting their expectations as well as thinking that seller's always giving attention on their needs. The perception of service positively influences the perception of product quality in Malaysian Street Food.

From the result, all the five statements under organization factor are also agreed by the consumers that organization will affect their perception of product quality based on the arrangement of the product, the variety of the product, the good decorations and the vendor sell interesting item. Lastly the consumers feel neutral about the healthiness perception of Malaysian street food. All the statements under healthiness perception is range from $3.0-$ 3.9 where it is considered neutral. Based on consumers' perspectives, it is neither easy nor difficult to get healthy food. Most of them feel neutral about the importance of healthy food and being particular about healthy food. It is true that healthiness perception is positively influences the perception of product quality towards Malaysian street food by the consumers. Schnettler et al. (2015) stated that the perspectives of healthiness in food consume is unintentionally related with disease precaution and improvement of health. From the mean result,

The mean for each factor will determine which factor will be the most influence factor that impact the perception of product quality towards Malaysian street food.

Table 3: Mean for each factor

\begin{tabular}{ll}
\hline Variables & Mean \\
\hline Cleanliness & 4.476 \\
\hline Organization & 4.368 \\
\hline Service & 4.058 \\
\hline Healthiness & 3.448 \\
\hline
\end{tabular}

As conclusion, the most influential factor that affects the perception of product quality towards Malaysian street food is cleanliness. It is proofed by the result in Table 12 . The 
consumer observant in every single detail about the cleanliness from the environment to the cleanliness of the food. Cleanliness factor has the highest mean which is 4.476 and it is enough to proof that cleanliness is the most influential factor that affects the perception of product quality. The last objective of this study is achieved as the cleanliness factor is the most influential factor compared to the other factors. The least influential factor is healthiness as the consumers do not put healthiness of the food as important as cleanliness. The mean of healthiness variables is 3.448 which is the lowest mean between other variables.

It is also because of sometimes it is not easy to find healthy food in Malaysia night market or street market. This is due to limited amount of healthy foods available in Malaysia night market or street market. Hence, the reasons will affect the healthiness perception towards product quality perception.

\section{Conclusion}

Street food sector development provides easy access to cheap food and new opportunities for jobs in the cities. Although this trend is optimistic in many ways, it also raises new challenges for the urban population in terms of public health (Rheinländer et al., 2008). Benny-Ollivierra and Badrie (2007) say that street food vendors should be educated in safe practices. Nutrition, food safety, risk analysis, vital control and preventive measures, environmental sanitation and personal hygiene should be part of the training.

In this study the researcher was able to identify the most influential consumer perception of Malaysian street food quality purchase intention, among four factors; service, organization, healthiness and cleanliness. The analysis shows that cleanliness of the location is the highest positively influences the perception of product quality in Malaysian Street Food with the highest mean 4.6900 and Organization also positively influences the perception of product quality in Malaysian street food with second highest mean after cleanliness with 4.600, contrary to what has been found in literature Drechsel et al., (2000); Probst, (2008); Rheinländer et al (2008); Schroeder et al., (2007); Van Der Geest (1998) that put more emphasize on service. Service provided at the vendor also positively influences the perception of product quality in Malaysian street food, Fontanillas et al (2013) and Rossi et al. (2012) show that the service provided is crucial to the understanding of quality by the consumers. Furthermore, the perception of health positively affects the perception of product quality with the lowest mean, 3.0100, corroborating Viana (2013), who connects the perception of health and the perception of product quality.

While conducting this study, there are some restraints that had been faced by the researches due to time and funds constrains. Therefore, recommendations to improve the study in helping future research are necessary. Firstly, future research should try to widen the data collections and try to get more respondents that would be able to give a more generic perspective regarding the issues. Secondly it is imperative to cover street food that is not operating within the compound of Pasar Malam, these stalls that are selling food stuff by the roadside at a permanent location are more prone to become complacent with hygiene practices. Thirdly the questionnaire needed to be refined and analyzed by using analysis to ensure better measurement. The analysis could also be extended to cover a wider and more sophisticated investigation. 
Personal hygiene and training should be focused by street food vendors which is related to the cleanliness and healthiness factor in the study. The improvement in hygiene with Malaysian street food operator will be able reduce issue regarding foodborne illness in the future. Furthermore, food need to be handled by following a minimum requirement of standard to avoid any cross contamination. Moreover, the seller should present the products as a healthy product since healthy products are also related to the product quality. Malaysian street operator is rarely offering an option nutritious food, and this is the time to make some changes and make a difference by increasing healthy food sector in street food vendor. The government needs to approach the vendors and impose stricter enforcement of food safety laws with focus on hazard analysis and training and offer training to improvement on service standards and attitudes.

\section{Corresponding Author}

Firdaus Abd Hanan. Faculty of Hotel and Tourism Management, Universiti Teknologi MARA, Puncak Alam Campus, 42300, Selangor, Malaysia.

E-mail: firdaushanan@uitm.edu.my

\section{References}

Alexander, J. (2006), Malaysia, Brunei and Singapore, Cadogan Guides.

Alimi, B. A. (2016), "Risk factors in street food practices in developing countries: a review", Food Science and Human Wellness, 5(3), 141-148.

Almeida, S. P., Araujo, R. M., Mota, P. S., Barros, M. S., and Mendonça, M. C. (2014), "Percepção de qualidade de um bar da orla de Aracaju-SE pelos frequentadores: estudo de caso", Scientia Plena, 10(6), 1-13.

Alves da Silva, S., Cardoso, R., de C. V., Góes, J. Â. W., Santos, J. N., Ramos, F. P., Bispo de Jesus, R., ... Teles da Silva, P. S. (2014). Street food on the coast of Salvador, Bahia, Brazil: A study from the socioeconomic and food safety perspectives. Food Control, 40(1), 788.

Arnold, D. M., Burns, K. E., Adhikari, N. K., Kho, M. E., Meade, M. O., Cook, D. J. (2009) McMaster Critical Care Interest Group. The design and interpretation of pilot trials in clinical research in critical care. Crit Care Med., 37(1), 69-74.

Asiegbu, C. V., Lebelo, S. L., \& Tabit, F. T. (2016). "The food safety knowledge and microbial hazards awareness of consumers of ready-to-eat street-vended food". Food Control, 60, 422-429.

Basinski, S. (2014). Hot dogs, hipsters, and xenophobia: Immigrant street food vendors in New York. Social Research: An International Quarterly, 81(2), 397-408.

Bellia, C., Pilato, M., \& Seraphin, H. (2016). Street food and food safety: a driver for tourism? Calitatea, 17(S1), 20-27.

Benny-Ollivierra, C., \& Badrie, N. (2007). Hygienic practices by vendors of the street food 'doubles' and public perception of vending practices in Trinidad, West Indies. Journal of Food Safety., Vol. 27 No. 1, pp. 66-81.

Bentler, P. M., \& Chou, C. P. (1987). Practical issues in structural modeling. Sociological Methods and Research, Vol. 16 No. 1, pp. 78-117.

Bezerra, A. D., Reis, R. B., \& Bastos, D. M. (2010). Microbiological quality of hamburgers sold in the streets of Cuiabá - MT, Brazil and vendor hygiene-awareness. Ciência $e$ Tecnologia de Alimentos, 30(2), 520-524. 
Brunso, K., Fjord, T. A., \& Grunert, K.G. (2002). Consumers' Food Choice and Quality Perception. The Aarhus School of Business, Aarhus.

Bryman, A., and \& Bell, E. (2011). Business Research Methods. $3^{\text {rd }}$ Ed., Oxford University Press, Oxford

Burt, B. M., Volel, C., \& Finkel, M. (2003). Safety of vendor-prepared foods: Evaluation of 10 processing mobile food vendors in Manhattan. Public Health Reports, 118(5), 470-476.

Byrne, B. M. (2010). Structural Equation Modeling with AMOS: Basic Concepts, Applications, and Programming, $2^{\text {nd }} E d$. Routledge, New York: NY.

Campbell, P. T., Ngoc, T., Thanh, C., Reviewers, P., Iwu, A. C., Uwakwe, \& Kosatsky, K. T. (2011). Assessing the Knowledge, Attitudes and Practices of Street Food Vendors in the City of Johannesburg regarding Food Hygiene and Safety. Food Control, 30(May), 150-156.

Canet, C., \& N'Diaye, C. (1996). Street foods in Africa. Food Nutrition and Agriculture (17/18), 4-13.

Castle, J. E. (2003). Maximizing research opportunities: Secondary data analysis., Journal Neurosci Nurs; 35: 287-290.

Sezgin, C. A., \& Şanlıer, N. (2016). Street food consumption in terms of the food safety and health. Journal of Human Sciences, 13(3), 4072-4083.

Creswell. (1998). Collecting Data in Mixed Methods Research. Retrieved December 29, 2018, https://www.sagepub.com/sites/default/files/upm-binaries/10983_Chapter_6.pdf

Department of Statistics Malaysia. (2010). Population Distribution and Basic Demographic Characteristic Report. Putrajaya.

Dewanti-Hariyadi, R., \& Gitapratiwi, D. (2014). In Y. Motarjemi (Vol. Ed.), Foodborne diseases: Prevalence of foodborne diseases in South East and central Asia. Encyclopedia of food safety: ume 1, (pp. 287-294). Amsterdam: Elsevier.

Drechsel, P., Abaidoo, R. C., Amoah, P., and and Cofie, O. O. (2000), Increasing use of poultry manure in and around Kumasi, Ghana: is farmers' race consumers' fate, Urban Agricultural Magazine, 2, 25-27.

Edema, M. O., \& Omemu, A. M. (2004). Microbiology and food hygiene in public food services. In proceedings of the international conference on science and national development (pp. 25-29). 25th-28th October 2004.

Ekanem, E. O. (1998). The street food trade in Africa: safety and socio-environmental issues. Food Control, 9(4), 211-215.

Firestone, W. A. (1987). Meaning in method: the rhetoric of quantitative and qualitative research. Educational Researcher. 16(7), 16-21.

Fontanillas, C. N., Cruz, E. P., and Ferreira, S. L. (2013), "A utilização dos fatores críticos de sucesso Para um restaurant", XXXIII Encontro Nacional de Engenharia de Produção, Salvador.

Food Safety Unit, Division of Food and Nutrition, WHO, Geneva (1996).

Green, S. B. (1991). How many subjects does it take to do a regression analysis? Multivariate Behavioral Research, 26, 499-510.

Grunert, K. G. (2010), "European consumers' acceptance of functional foods", Annals of the New York Academy of Sciences, 1190(1), 166-173.

Hill, R. (1998). What Sample Size is Enough in Internet Survey Research? Interpersonal Computing and Technology Journal, 3.

Hopkins, W. G. (2000). Quantitative Research Design. Sport Sci Journal, 2-3. 
Ibáñez Casanova, C. (2003), "Las unidades alimentarias y los mercados municipals", Distribución y Consumo, Vol. 69, pp. 47-53.

Kho, M. E., Meade, M. O., Cook, D. J., \& McMaster Critical Care Interest Group. (2009). The design and interpretation of pilot trials in clinical research in critical care. Critical care medicine, 37(1), 69-74.

Kok, R., \& Balkaran, R. (2014). Street Food Vending and Hygiene Practices and Implications for Consumers. Journal of Economics and Behavioral Studies, 6(3), 188-193.

McArt, E. W., \& McDougal, L.W. (2007). Secondary data analysis: A new approach to nursing research. J. Nurs. Sch.; 17: 54-57.

Muinde, O. K., \& Kuri, E. (2005). Hygienic and sanitary practices of vendors of street foods in Nairobi, Kenya. African Journal of Food Agriculture \& Nutritional Development, 5(1), 114.

Nicoll, L. H., \& Beyea, S. C. (1999). Using secondary data analysis for nursing research. AORN journal, 69(2), 428-433. https://doi.org/10.1016/s0001-2092(06)62504-0.

Oguntona, C. R. B., \& Kanye, O. (1995). Contribution of street foods to nutrient intakes by Nigerian adolescents. Nutrition Health, 10, 165-171.

Omemu, A. M., \& Aderoju, S. T. (2008). Food safety knowledge and practices of street food vendors in the city of Abeokuta, Nigeria. Food Control, 19(4), 396-402.

Carlbring, P., Brunt, S., Bohman, S., Austin, D., Richards, J., Öst, L. G., \& Andersson, G. (2007) Internet vs. paper and pencil administration of questionnaires commonly used in panic/agoraphobia research. Computers in Human Behavior, 23(3), 1421-1434.

Parry, S. M., Miles, S., Tridente, A., and Palmer, S. R. (2004). "Differences in perception of risk between people who have and have not experienced salmonella food poisoning". Risk Analysis: An Official Publication of the Society for Risk Analysis, 24(1), 289-299.

Rheinländer, T., Olsen, M., Bakang, J. A., Takyi, H., Konradsen, F., \& Samuelsen, H. (2008). Keeping up appearances: Perceptions of street food safety in urban Kumasi, Ghana. Journal of Urban Health, 85(6), 952-964.

Rossi, G. B., Silva, D., Debessa, F. N., and Garcia, M. N. (2012), "Percepção de valor dos consumidores de serviços de restaurantes: um estudo com modelagem de equações estruturais", Revista Brasileira de Marketing, Vol. 11 No. 3, pp. 27-53.

Santos, V. A., Santos, M. P., Matos, V. D., Lôbo, L. N., Freitas, F., and Silva, I. D. (2012), "Perfil dos consumidores de alimnetos de rua", Revista Baiana de Saúde Pública, 36(3), 777791.

Sawe, B. E. (2019). Ethnic Groups of Malaysia. https://www.worldatlas.com/articles/ethnicgroups-of-malaysia.html

Sekaran, U., \& Bougie, R. (2013). Research methods for business: A skill building Approach. Italy: John Wiley and Sons Ltd.

Sekaran, U. (2003). Research methods for business: A skill building approach. New Jersey: John Wiley and Sons Ltd

Singh, A. K., Dudeja, P., Kaushal, N., \& Mukherji, S. (2016). Impact of health education intervention on food safety and hygiene of street vendors: A pilot study. Medical Journal Armed Forces India, 72(3), 265-269.

Soon, J. M., Singh, H., Baine, R. (2011). Foodborne diseases in Malaysia: A review. Food Control Journal, 22(6), 823-830 
Tinoco, M. A., and Ribeiro, J. L. (2008), "Estudo qualitativo dos principais atributos que determinam a percepção de qualidade e de preço dos consumidores de restaurantes a la carte", Gestão and Produção, 15(1), 73-87.

Tiwari, P., and Verma, H. (2008), "Consumer perception about fast food in India: an empirical study of Dehradun City", ICFAI Journal of Consumer Behavior, 3(4), 80-91.

Trafialek, J., Drosinos, E. H., Laskowski, W., Jakubowska-Gawlik, K., Tzamalis, P., Leksawasdi, N., ... Kolanowski, W. (2018). Street food vendors' hygienic practices in some Asian and EU countries - A survey. Food Control, 85, 212-222.

Van Seventer, J. M., \& Hamer, D. H. (2017). Foodborne diseases. In S. R. Quah (Ed.). International encylopedia of public health (pp. 160-173). Amsterdam: Elsevier.

World Health Organization (WHO). (2009), Essential Safety Requirements for Street Vended Foods (Revised Edition), Rome.

World Health Organization (WHO). (1999). Food Safety: An Essential Public Health Issue for the New Millennium Food Safety Programme, Department of Protection of the Human Environment, Cluster of Sustainable Development and Healthy Environments, WHO, Geneva World Health Organization (WHO), 1996. 